\title{
Pengembangan Modul Perhitungan Rumus Kimia dan Persamaan Reaksi Berbasis Inkuiri Terstruktur dengan Tiga Level Representasi untuk Kelas X SMA/MA
}

\author{
M P Sari ${ }^{1}$ and M Azhar ${ }^{*}$ \\ ${ }^{1}$ Pendidikan Kimia, Universitas Negeri Padang, Jl. Prof. Dr. Hamka Air Tawar Barat, \\ Padang Utara, Sumatera Barat 25171, Indonesia \\ *minda@fmipa.unp.ac.id
}

\begin{abstract}
Module of chemical formula and reaction equation with three levels representation based structured inquiry had been determined validity and practility. The research type was research and development (R\&D). The development model was 4-D model the consist of 4 stages, namely: define, design, develop and disseminate. This research was limited to the stage of development, namely the validity and practicality tests. The research instruments were used observation questionnaire, validity and practicality. The modul was validated by 5 validators. Practicality test was carried out by 2 chemistry teachers and 24 XI grade students of IPA 2 SMAN Basa Ampek Balai. Data of the validity and practicality test were analyzed using the cohen kappa formula. The average kappa moment of validity test was 0,93 with a very high validity category. The average kappa moment of teacher and student practicality were 0,88 and 0,91 respectively with category very high practicality category.Thus, module of chemical formula and reaction equation with three levels representation based structured inquiry was valid and practice.
\end{abstract}

\section{Pendahuluan}

Perubahan kimia dapat dinyatakan dengan persamaan reaksi kimia. Persamaan reaksi adalah simbolsimbol kimia yang menyatakan perubahan reaktan menjadi produk. Dalam perubahan kimia bagian yang penting untuk dipelajari adalah penggunaan rumus kimia untuk menjelaskan reaksi dan menentukan jumlah zat yang terlibat dalam reaksi [1]. Oleh karena itu, untuk menentukan jumlah zat yang terlibat dalam reaksi dapat menggunakan persamaan reaksi. Simbol-simbol kimia pada persamaan reaksi sulit dipahami siswa. Siswa mengalami kesulitan memahami persamaan kimia, konsep mol dan perhitungan dalam reaksi kimia. Kesulitan lain yang ditemukan siswa dalam penyetaraan persamaan reaksi kimia adalah menginterpresentasikan permasalahan dalam kata-kata menjadi persamaan yang sistematis [2].

Kesulitan siswa mempelajari persamaan reaksi disebabkan karena pembelajaran persamaan reaksi hanya pada level makro dan simbolik. Pemahaman pada konsep persamaan reaksi hendaknya menekankan pada tiga level representasi kimia, yaitu makroskopik, submikrokopis, dan simbolik. Kemampuan seseorang dalam menginterkoneksikan tiga level representasi kimia menentukan tingkat pemahamannya terhadap suatu materi serta memberikan pemahaman konsep yang utuh kepada siswa.

Ketiga level representasi hendaknya dimasukkan dalam proses pembelajaran, salah satunya pada bahan ajar. Bahan ajar yang sesuai mempengaruhi ketercapain tujuan pembelajaran. Bahan ajar dikelompokan menjadi empat, yaitu bahan ajar cetak, bahan ajar dengan audio, bahan ajar pandang dengar, dan bahan ajar interaktif. Salah satu contoh bahan ajar cetak yaitu modul. Modul merupakan seperangkat unit materi yang terdiri dari rangkaian kegiatan pembelajaran yang disusun secara sistematis untuk membantu tercapainya tujuan pembelajaran yang dirumuskan [3].

Dalam mencapai tujuan pembelajaran diperlukan pendekatan pembelajaran yang sesuai. Berdasarkan kurikulum 2013 pendekatan yang sesuai digunakan yaitu pendekatan saintifik. Pendekatan saintifik adalah pendekatan pembelajaran yang berpusat kepada siswa. Salah satu model pembelajaran yang 
mengunakan pendekatan saintifik yaitu inkuiri. Inkuiri adalah suatu model pembelajaran yang berpusat pada siswa untuk dapat menemukan, mengetahui, mendalami suatu konsep atau memecahkan suatu permasalahan secara sistematis, kritis, logis, dan ilmiah [4].

Proses pembelajaran mengunakan inkuiri dikelompokkan menjadi empat macam, yaitu inkuiri konfirmasi, inkuiri terstruktur, inkuiri terbimbing, dan inkuiri terbuka. Dari keempat kelompok inkuiri, inkuiri terstruktur merupakan inkuiri yang paling tepat digunakan, karena untuk menyetarakan persamaan reaksi memerlukan beberapa tahapan, yaitu menentukan rumus kimia dari reaktan dan produk, menentukan jumlah atom dari masing-masing unsur, sehingga tepat digunakan.

Pembelajaran menggunakan inkuiri terstruktur, menuntunt siswa untuk menyelidiki dan menyelesaikan permasalahan yang diberikan guru melalui langkah-langkah dan prosedur yang telah ditentukan. Untuk memperoleh hasil yang diinginkan, siswa melakukan penyelidikan secara langsung dan mengembangkan kemampuan dasarnya dalam penyelidikan yaitu melakukan pengamatan, hipotesis, mengumpul dan mengolah data serta membuat kesimpulan dan menemukan solusi [5]. Penggunaan model inkuiri terstruktur dapat meningkatkan minat belajar peserta didik, partisipasi aktif peserta didik, kinerja guru dan hasil belajar [6]. Pengembangan modul konsep mol berbasis inkuiri terstruktur dengan penekanan pada interkoneksi tiga level representasi kimia dapat meningkat hasil belajar siswa [7].

Berdasarkan latar belakang di atas, maka penelitian pengembangan modul pada perhitungan rumus kimia dan persamaan reaksi berbasis inkuiri terstruktur dengan tiga level representasi kimia penting dilakukan. Penelitian ini bertujuan untuk menghasilkan modul perhitungan pada rumus kimia dan persamaan reaksi berbasis inkuiri terstruktur dengan tiga level representasi kimia untuk kelas X SMA.

\section{Metode}

Jenis penelitian ini adalah Research and Development (R\&D). Penelitian R\&D ialah penelitian yang bertujuan untuk menghasilkan produk [8]. Model penelitian dan pengembangan yang digunakan adalah model 4-D, yang terdiri dari empat tahapan, yaitu define, design, develop, dan desseminat. Langkahlangkah tahap define yaitu, 1) analisis ujung depan, 2) analisis siswa, 3) analisis tugas, 4) analisis konsep dan 5) analisis tujuan pembelajaran. Tahap design, modul perhitungan pada rumus kimia dan persamaan reaksi berbasis inkuiri terstruktur dengan tiga level representasi kimia untuk kelas X SMA di rancang. Modul dirancang sesuai dengan komponen modul [9]. Tahap develop, bertujuan untuk mengasilkan modul perhitungan pada rumus kimia dan persamaan reaksi berbasis inkuiri terstruktur dengan tiga level representasi yang valid dan praktis. Pada tahapan ini dilakukan uji validasi dan uji praktikalitas.

Penelitian ini dibatasi sampai penentuan validitas dan praktikalitas modul perhitungan pada rumus kimia dan persamaan reaksi. Subjek penelitian ini terdiri 3 dosen kimia, 2 guru kimia SMA dan 24 siswa. Data yang didapat dioleh dengan menggunakan moment kappa Cohen[10].

\begin{tabular}{c|l}
\multicolumn{2}{c}{$\frac{\rho-\rho e}{1-\rho e}$} \\
$\mathrm{k}=$ & moment kappa \\
\hline$\rho=$ & $\begin{array}{l}\text { proporsi yang terealisasi, dihitung dengan cara jumlah yang diberikan validator dibagi } \\
\text { dengan jumlah maksimal }\end{array}$ \\
\hline$\rho e$ & $\begin{array}{l}\text { proporsi yang tidak terealisasi, dihitung dengan cara jumlah nilai maksimal dikurangi } \\
\text { dengan jumlah total dibagi dengan jumlah nilai maksimal }\end{array}$
\end{tabular}

Tabel 1. Kategori keputusan berdasarkan moment kappa

\begin{tabular}{c|c} 
Interval & Kategori \\
\hline $0.81-1.00$ & Sangat Tinggi \\
\hline $0.61-0.80$ & Tinggi \\
\hline $0.41-0.60$ & Sedang \\
\hline $0.21-0.40$ & Rendah \\
\hline $0.01-0.20$ & Sangat Rendah \\
\hline$<0.00$ & Tidak Valid
\end{tabular}


Instrumen yang digunakan adalah angket observasi, angket validasi dan praktikalitas. Angket validasi digunakan untuk menilai validitas modul perhitungan pada rumus kimia dan persamaan reaksi berbasis inkuiri terstruktur dengan tiga level representasi kimia yang dinilai oleh 3 dosen kimia UNP dan 2 guru SMA. Penilaian validitas modul dilihat dari 4 komponen, yaitu 1) Komponen kelayakan isi, 2) kompnen penyajian, 3) komponen kebahasaan dan 4) komponen kegrafisan. Setelah dilakukan validasi maka akan dilakukan revisi sesuai dengan saran yang diberikan oleh validator, sehingga bisa dilanjutkan untuk melihat kepraktisan modul.

\section{Hasil dan Diskusi}

Berdasarkan tujuan penelitian dan jenis penelitian R\&D yang menggunakan model pengembangan 4D, sehingga dihasilakn modul perhitungan pada rumus kimia dan persamaan reaksi berbasis inkuiri terstruktur dengan penekanan pada tiga level representasi kimia untuk kelas X SMA. Model pengembangan 4-D terdiri dari beberapa tahap yaitu

\subsection{Tahapn define (pendefenisian), yang terdiri dari beberapa tahapan yaitu}

3.1.1. Analisis ujung depan, Analisis ujung depan dilakukan dengan pengisian angket yang diberikan kepada siswa SMA Pembangunan Laboratoriu UNP. Sekitar 57\% siswa tidak memahami materi persamaan reaksi. Hal ini juga sesuai dengan hasil wawancara salah satu guru kimia SMA Pembangunan Laboratoriu UNP yang menyatakan bahwa siswa kurang memahami materi persamaan reaksi. Belum tersedianya modul perhitungan pada rumus kimia dan persamaan reaksi berbasis inkuiri terstruktur dengan tiga level representasi kimia. Modul merupakan bahan ajar mandiri, yang berisi serangakain kegiatan yang dapat membantu siswa belajar mandiri [11].

3.1.2. Analisis siswa. Analisis siswa dilakukan dengan pengisian angket oleh siswa SMA Pembangunan Laboratoriu UNP dan SMAN 1 Basa Ampek Balai. Usia siswa SMA sekitar 15-17 tahun, termasuk kepada tahap operasional formal [12]. Tahap opersional formal ialah tahapan dimana seseorang sudah mampu berfikir abstrak, bernalar secara logis, serta mengambil kesimpulan terhadap informasi yang telah disediakan.

3.1.3. Analisis tugas. Analisis tugas meliputi tugas yang dikerjakan siswa sesuai dengan materi pembalajaran, yaitu rumus kimia dan persamaan reaksi. Tahapan yang dilakukan pada analisis tugas yaitu dengan menguraikan kompetensi dasar (KD) menjadi indikator pencapaian kompetensi (IPK) dan dijadikan tujuan pembelajaran. Kompetensi dasar materi perhitungan pada rumus kimia dan persamaan reaksi terdapat pada KD 3.10. Menerapkan hukum-hukum dasar kimia, konsep massa molekul relatif, persamaan kimia, konsep mol,dan kadar zat untuk menyelesaikan perhitungan kimia [13]. Indiaktor pencapaian kompetensi, yaitu 1) Menjelaskan pengetian mol berdasarkan data yang diberikan. 2) Menentukan massa molar suatu unsur dan senyawa berdasarkan massa atom. 3) Menghitung volume molar gas berdasarkan nilai mol yang diketahui. 4) Menentukan rumus empiris suatu senyawa berdasarkan data experimen. 5) Menentukan rumus molekul suatu senyawa berdasarkan rumus empiris. 6) Menjelaskan makna subscript pada rumus kimia. 7) Menjelaskan pengertian persamaan reaksi. 8) Menyetarakan persamaan reaksi dan 9) mengaplikasikan persamaan reaksi untuk

3.1.4. Analisis konsep. Konsep-konsep yang terdapat pada materi rumus kimia dan persamaan reaksi disusun secara hirarki menjadi peta konsep. Konsep-konsep tersebut dianalisis berdasarkan buku kimia universitas dan kimia SMA. Beberapa konsepnya, yaitu mol, rumus kimia, persamaan reaksi, rumus empiris, rumus molekul, rumus struktur, senyawa kovalen, senyawa ion, reaktan pembatas dan reaktan berlebih.

3.1.5. Analisis tujuan pembelajaran. Tujuan pembelajaran diturunkan berdasarkan indikator pencapain kompetensi (IPK). Tujuan pembelajaran yaitu Melalui model pembelajaran inkuiri terstruktur dengan menggali informasi dari berbagai sumber, penyelidikan sederhana dan pengolahan informasi, diharapkan peserta didik terlibat aktif selama proses belajar mengajar berlangsung, memiliki sifat ingin tahu, teliti dalam melakukan pengamatan dan bertanggung jawab dalam menyampaikan pendapat, 
menjawab pertanyaan, memberi saran, kritikan, serta peserta didik mampu memahami konsep mol, rumus kimia, persamaan reaksi, menyetarankan persamaan reaksi, serta mengaplikasikan persamaan reaksi untuk menentukam reaktan pembatas.

3.1.5.1. Tahap Design (Perancangan). Pada tahap perancangan disesuai dengan hasil pengisian angket siswa SMA Pembangunan, yang mana siswa menginkan modul yang mudah dipahami, menarik dan bergambar. Modul perhitungan pada rumus kimia dan persamaan reaksi dirancang yang terdiri dari 1) cover; 2) kata pengantar; 3) daftar isi; 4) petunjuk penggunaan modul; 5) kompetensi inti; 6) kompetensi dasar; 7) indikator pencapaian kompetensi; 8) tujuan pembelajaran; 9) pendahuluan; 10) peta konsep; 11) lembar kegiatan; 12) lembar kerja; 13) lembar evaluasi ; 14) kunci jawaban lembar kegiatan; 15) kunci jawaban lembar kerja; 16) kunci jawaban evaluasi. Cover, lembar kegiatan dan kunci jawaban lembar kegiatan dapat dilihat pada Gambar $1-3$.

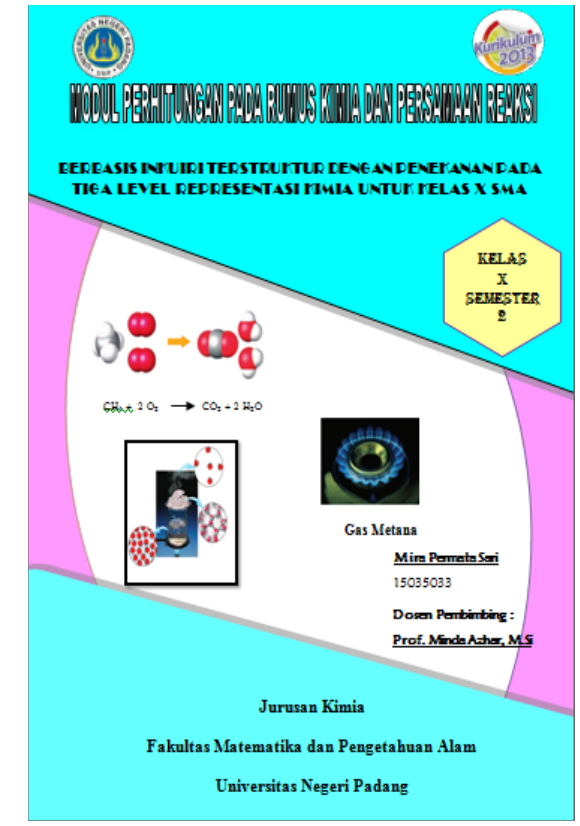

Gambar 1. Cover Modul

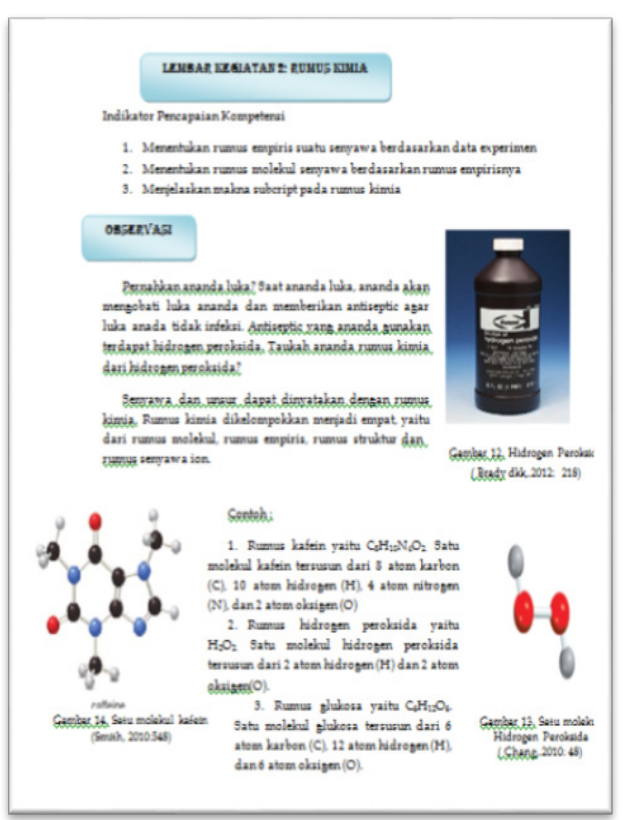

Gambar 2. Lembar kegiatan 


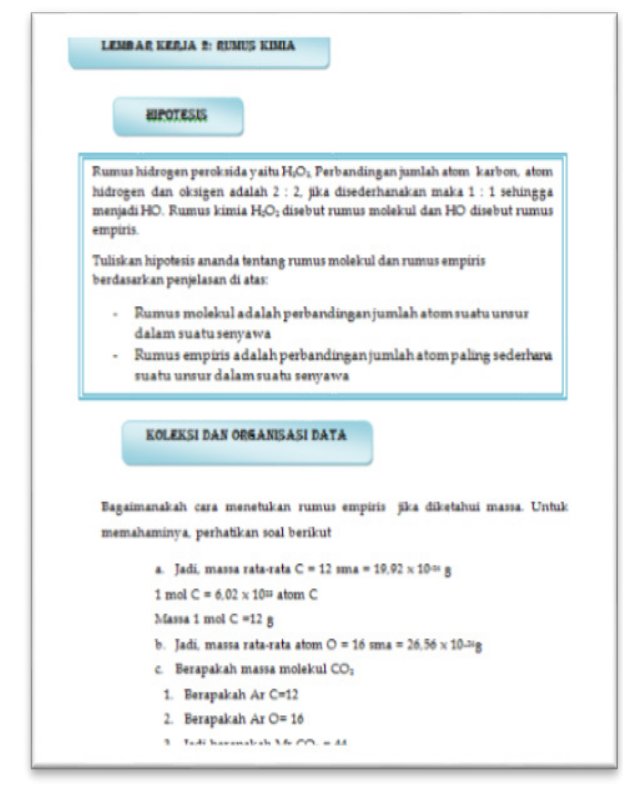

Gambar 3. Kunci lembar kegiatan

\subsection{Tahap develop (pengembangan)}

3.2.1. Uji Validasi. Uji valiadsi merupakan penilaian produk oleh validator. Penilaian modul perhitungan pada rumus kimia dan persamaan reaksi di lakukan oleh 3 dosen kimia UNP dan 2 guru SMAN 1 Basa Ampek Balai Tapan. Hasil penilaiannya dapat dilihat pada Gambar 4.

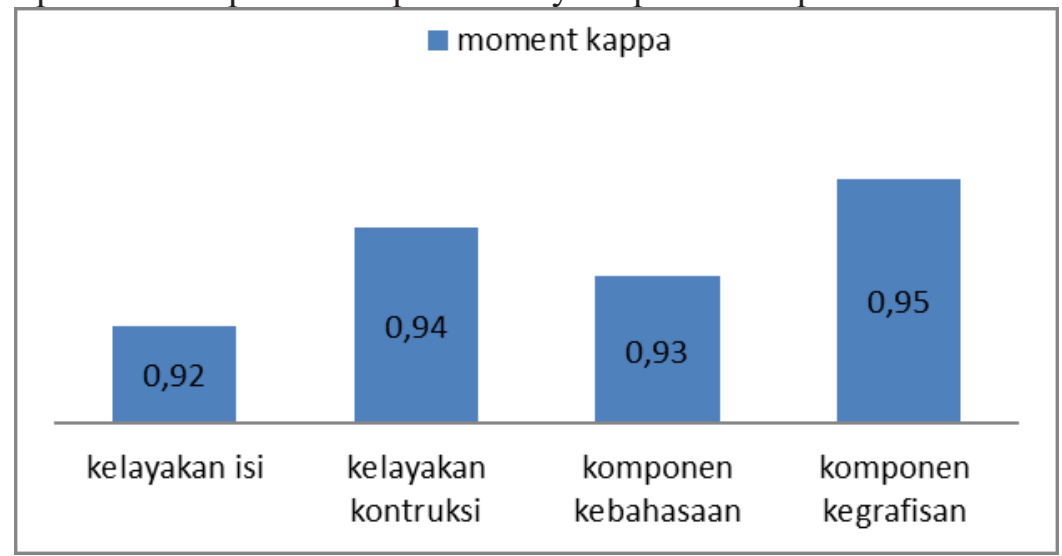

Gambar 4. Moment Kappa validasi modul perhitungan pada rumus kimia dan persamaan reaksi berbasis inkuiri terstruktur dengan penekanan pada tiga level representasi kimia kelas X SMA

Empat komponen penilaian validasi modul perhitungan pada rumus kimia dan persamaan reaksi berbasis inkuiri terstruktur dengan penekanan pada tiga level representasi kimia kelas X SMA, yaitu komponen kelayakan isi, kelayakan kontruksi, komponen kebahasaan, dan komponen kegrafisan [14]. Penilaian valiadtor untuk keempat komponen tersebut dianalisis menggunakan moment kappa. Diperoleh moment kappa rata-rata terhadap keempat komponen tersebut yaitu 0,94 dengan kategori sangat tinggi.

Komponen kelayakan isi, diperoleh moment kappa rata-rata sebesar 0,92 dengan kategori sangat tinggi. Hal ini menjelaskan bahwa modul yang dikembangkan sudah sesuai dengan kompetensi inti dan kompetensi dasar yang terdapat pada silabus 2018 kurikulum 2013. Modul yang dikembangakan harus berisi kompetensi sesuai dengan kurikulum yang berlaku. Selain itu pertanyaan-pertanyaan yang disajikan menuntun siswa untuk menemukan konsep sehingga indikator dan tujuan pembelajaran dapat tercapai. Pertanyaan yang diberikan tidak ambigu dan diberikan latihan yang membantu siswa dalam memantapkan konsep. Isi modul telah sesuai telah memperlihatkan tiga lvel representasi yang benar secara keilmuan. Modul dinyatakan memiliki kelayakan isi apabila terdapat sesuai materi dengan KI dan 
$\mathrm{KD}$, tujuan pembelajaran, dan kemampuan siswa [15].

Komponen penyajian, diperoleh moment kappa rata-rata sebesar 0,94 dengan kategori sangat tinggi. Tingginya hasil kevalidan modul dijelaskan karena modul rumus kimia dan persamaan reaksi disusun secara sistematis sesuai dengan komponen-komponen modul. Modul disusun berdasarkan tahapan inkuiri terstruktur yaitu observasi, hipotesis, koleksi dan organisasi data dan kesimpulan. Pada tahapan hipotesis, menentun siswa untuk merumuskan penyataan untuk menyelidikan. Pada tahapan koleksi dan organisasi data memimbing siswa untuk menemukan konsep melalui pertanyaan dan data informasi, serta pada tahap kesimpulan siswa membuat kesimpulan dengan bahasanya sendiri. Pertanyaan-pertanyaan yang diberikan mengambarkan tujuan yang ingin dicapai. Pada pembelajaran menggunakan model inkuiri terstruktur, penemuan konsep dilakukan oleh siswa melalui penyelidikan secara langsung [16].

Komponen kebahasaan, diperoleh moment kappa rata-rata sebesar 0,93 dengan kategori sangat besar. Tingginya hasil kevalidan modul karena pertanyaan yang diajukan sudah sesuai dengan tata kebahasaan, dan konsisten dalam menggunakan modul. Modul yang menggunakan bahasa yang komunikatif dan sederhana membuat siswa mudah memahami materi, sehingga meningkatkan minat dan pemahaman konsep peserta didik [17].

Komponen kegrafisan, diperoleh moment kappa sebesar 0,95 dengan kategori sangat tinggi. Tingginya hasil kevalidan karena modul menampilkan gambar, jenis huruf, tata letak dan warna yang sesuai dan jelas, sehingga menarik perhatian siswa untuk belajar. Kesesuai tata letak pada modul dapat meningkatkan motivasi siswa dalam belajar [18].

3.2.2. Revisi. Tahap revisi bertujuan untuk bagaian modul yang tidak sesuai, berdasarkan saran yang diberikan oleh validator. Bagian-bagian modul yang direvisi yitu 1) Cover modul, Beberapa kalimat yang ada pada cover perlu di tebalkan, 2) konsisten dalam menentukan ukuran submikro pada setiap unsur.

3.2.3. Uji Praktikalitas. Modul diuji kepraktikalitasnya pada tiga komponen yaitu kemudahan penggunaan, efisiensi waktu pembelajaran, dan manfaat. Hasil analisis data praktikalitas oleh guru da siswa terhadap modul perhitungan pada rumus kimia dan persamaan reaksi berbasis inkuiri terstruktur dengan penekanan pada tiga level representasi kimia dapat dilihat pada Gambar 5.

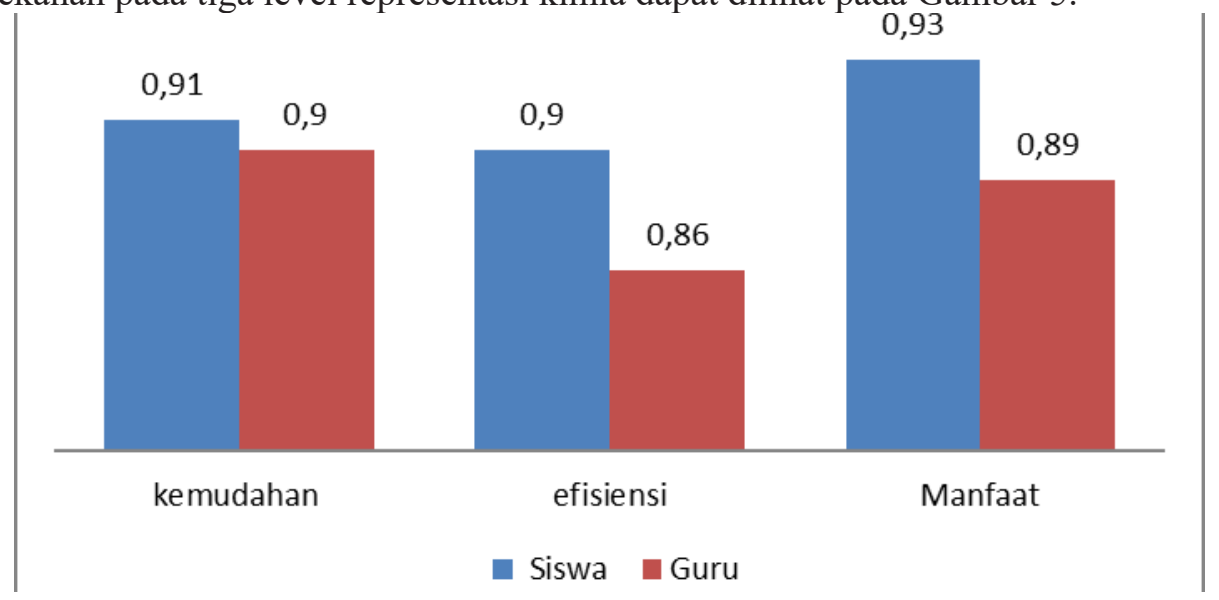

Gambar 5. Moment Kappa praktikalitas modul perhitungan pada rumus kimia dan persamaan reaksi berbasis inkuiri terstruktur dengan penekanan pada tiga level representasi kimia kelas X SMA

Aspek kemudahan modul mempunyai rata-rata moment kappa dari guru yaitu 0,9 sedangkan siswa 0,91 dengan kategori sangat tinggi. Hal menjelaskan bahwa modul perhitungan pada rumus kimia dan persamaan reaksi secara keseluruhan mudah di pahami, menggunakan huruf yang jelas, dan mudah di bawa. Secara umum, modul membantu siswa untuk mudah mengikuti proses pembelajaran agar tercapai tujuan pembelajaran[19].

Aspek efisiensi waktu pembelajaran mempunyai moment kappa rata-rata yaitu 0,86 dari guru dan 0,9 dari siswa dengan kategori sangat tinggi. Hal ini menjelakan bahwa modul perhitungan pada rumus kimia dan persamaan reaksi membantu proses pembelajran lebih efisien. Komponen manfaat mempunyai moment kappa rata-rata 0,89 dari guru dan 0,93 dari siswa dengan kategori sangat tinggi. 
Hal ini menjelaskan bahwa modul perhitungan pada rumus kimia dan persamaan reaksi membantu siswa dalam memahami konsep, design modul menarik sehinngga siswa menjadi senang belajar kimia.

Hasil rata-rata modul perhitungan pada rumus kimia dan persamaan reaksi oleh 2 guru kimia yaitu 0,88 dengan kategori sangat tinggi dan dari 24 siswa yaitu 0,91 dengan kategori sangat tinggi. Hal ini menjelakan bahwa modul perhitungan pada rumus kimia dan persamaan reaksi berbasis inkuiri terstruktur dengan penekanan pada tiga level representasi kimia praktis dan dapat digunakan di sekolah.

\section{Simpulan}

Berdasarkan penelitian yang telah dilakukan, dapat disimpulkan bahwa dihasilkan modul perhitungan pada rumus kimia dan persamaan reaksi berbasis inkuiri terstruktur dengan tiga level representasi kimia kelas X SMA. Modul yang dihasilkan mempunyai kevalidan dan kepraktisan sangat tinggi

\section{Referensi}

[1] Brown, dkk. Chemistry the central science. USA: Pearson Education

[2] Zakiyah,dkk. 2018. Analisis Dampak Kesulitan Siswa pada Materi Stoikiometri Terhadap Terhadap Hasil Belajar Termokimia. Jurnal kimia dan pendidikan. Vol. 3.No. 1.

[3] Sabri, Ahmad. 2013. Strategi BelajarMengajar dan Micro Teaching. Bandung: Ciputat Press.

[4] Nurdin, Syafrudin dan Adriantoni. 2016. Kurikulum dan Pembelajaran. Jakarta : Rajagrafindo Persada.

[5] Zion. 2012. Moving From Structured To Open Inquiry: Challnger and Limits. Jurnal Science education internal.

[6] Sugiarto. 2015. Peningkatan Hasil Belajar Materi Getaran dan Gelombang Melalui Pembelajaran berbasis inkuiri terstruktur. Jurnal penelitian tindakan kelas.

[7] Sagita, Randa. 2017. Pengembangan Modul Konsep Mol Berbasis Inkuiri Terstruktur Dengan Penekana Pada Interkoneksi Tiga Level Representasi Kimia Untuk Kelas X SMA. Jurnal eksata pendidikan. Vol.1.No.2.

[8] Sugiyono. 2013. Metode penelitian kuantitatif kualitatif dan $R \& D$. Bandung . Alfabet.

[9] Purwanto, Djanji. 2014. Evaluasi hasil belajar. Yogyakarta: Pustaka Pelajar.

[10] Boslaugh, S., \&Watters, P. A. (2008). Statistics in a nutshell (ORielly). Book.

[11] Nasution. 2015. Berbagai Pendekatan Dalam Proses Belajar dan Mengajar. Jakarta: Bumi Aksara.

[12] Omrod, J. 2014. Psikologi pendidikan edisi ke-Enam. Jakarta: Erlangga.

[13] Permendikbud. 2018. Perubahan atas Menteri Pendidikan dan Kebudayaan No 24 tahun 2016 tentang Kompetensi Inti dan Kompetensi Dasar Pembelajaran Pada Kurikulum 2013 Pada pendidikan Dasar dan Menengah. Jakarta: Menteri pendidikan dan Kebudayaan Republik Indonesia.

[14] Depdiknas. 2008. Panduan pengembangan Bahan Ajar. Jakarta: Depertemen pendidikan Nasional Direktorat Manajement Pendidikan Dasar dan Menengah Direktorat Pembinaan Sekolah Menengah atas.

[15] Arifin, Zaenal. 2011. Evaluasi Pembelajaran. Bandung: Remaja Rosdakarya.

[16] Zion, M., \& Mendelovic, R. 2012. Moving From Structured to open inquiry: Chalsanges and limits. Science Education International, 23(4), 383-399.

[17] Lasmiyati. 2014. Pengembangan modul Pembelajaran Untuk Meningkatkan Pemahaman Konsep dan Minat SMP. Jurnal Pendidikan Matematika. Volume 9, Nomor 2, Halaman161-174.

[18] Wiyani, Novan Ardy. 2013. Desain Pembelajaran Pendidikan. Yogyakarta: Ar-ruzz Media.

[19] Nasution. 2015. Berbagai pendekatan Dalam Proses Belajar Mengajar. Jakarta: Bumi Aksa 